\title{
Research on the integration of curriculum ideological and political education, innovation and entrepreneurship education into professional curriculum system in higher vocational colleges under the new engineering background
}

\author{
Xiangli Dong* \\ Shandong Union College, Yaoqiang Town, Licheng District, Jinan City, China
}

\begin{abstract}
Under the background of new engineering, the traditional curriculum can no longer meet the purpose of talent training in higher vocational colleges. The curriculum system, curriculum resources, teaching staff, etc. need to be improved, especially the curriculum system should keep pace with The Times. This paper mainly studies the integration of Curriculum ideological and political education, Innovation and entrepreneurship education into the construction of professional curriculum system in higher vocational colleges under the background of new engineering. It mainly includes the overall framework, basic content and research value of the research. It also has reference value for other related majors. It plays an important demonstration and radiation role in the integration of subjects in school and the extension of influence outside school, and steadily improves the construction and teaching quality of professional courses in higher vocational colleges.
\end{abstract}

Keywords: The new engineering, Curriculum ideological and political education, Innovation and entrepreneurship education, Curriculum system.

\section{Introduction}

China is implementing major strategies such as innovation-driven development, "Made in China 2025" and "Internet +". To occupy a strategic commanding position in the future global innovation ecosystem, there is an urgent need to cultivate a large number of emerging engineering and scientific talents. A series of educational courses adapted to the development of The Times and suitable for students' professional knowledge and innovation and entrepreneurship are in urgent need of construction and development. Under the new situation of engineering, vocational education in higher vocational colleges should focus on cultivating innovative talents with high quality and high skills. In order to cultivate such

\footnotetext{
*Corresponding author: 778118795@qq.com
} 
talents, higher vocational colleges should strive to create conditions. Higher vocational colleges should strive to create conditions and analysis under the background of new era, new engineering innovative entrepreneurial goals technology of high-quality innovative national construction requirements, determine the talents training goal of high quality innovative technical skills and find new engineering under the background of entrepreneurial innovation national high-quality innovative technology skills training strategy. Chinese governments at all levels attach great importance to the cultivation of high-quality and skilled innovative talents, and have carried out beneficial exploration and practice in professional setting, curriculum system, curriculum resources and the construction of teaching staff. At present, the theoretical research and practical exploration of innovation education at home and abroad are also in full development, and a lot of successful experience has been obtained, which is worth our learning and reference. However, in the field of vocational education under the background of new engineering, how to effectively integrate ideological and political education, innovation and entrepreneurship education and professional curriculum system, and cultivate high-quality workers and technical and skilled talents in the new era on a large scale is an urgent problem to be solved.

\section{Overall research framework}

Under the new engineering background, "school-enterprise cooperation and course coconstruction", collaborative education. innovation of course teaching concept, construction of " Curriculum ideological and political education, Innovation and entrepreneurship education into the professional course system. Through imparting knowledge, shaping value and cultivating ability, the training goal of the course is achieved, and the high unity of regularity, value and purpose is achieved. The theory and practice curriculum system of "module + platform" is constructed to jointly cultivate and apply innovation and entrepreneurship ability. The theoretical curriculum system mainly includes four platforms, namely general education platform, discipline basic education platform, professional education platform and innovation and entrepreneurship education platform. The practical curriculum system mainly includes course experiment (training), concentrated practice, innovation and entrepreneurship practice and the second class, etc. Through the combination of online and offline teaching, we will explore the ideological and political elements of the course, integrate innovation and entrepreneurship education into the course teaching, complete the course content supply, and highlight the integrity, comprehensiveness and leadership. Excavate various curriculum resources integrating ideological and political elements, integrate explicit education with hidden education, combine strict and broad education, and adopt various methods and means, which are characteristic and effective. A multi-dimensional curriculum evaluation system is established to evaluate the teaching effect through subject evaluation, performance evaluation and process evaluation. Explicit education and implicit education are carried out in coordination to educate people from various angles and in an all-round way. Improve the teaching quality monitoring and guarantee system in the course construction process to ensure the smooth construction and effective implementation of the course system.

\section{Researching content}

The new standard of new engineering construction puts forward higher requirements for the professional curriculum system of higher vocational colleges. On the premise of following the teaching rules of vocational education and combining the actual situation of vocational colleges and students. Based on the new engineering background, the research discusses the 
role of Curriculum ideological and political education, Innovation and entrepreneurship education into integrating professional theoretical curriculum system, practical curriculum system, curriculum resources, teachers' teaching ability, curriculum assessment and curriculum construction. The Curriculum ideological and political education, Innovation and entrepreneurship education is integrated into professional teaching organizations and combined with the training of students' professional characteristics, so as to prepare for the training of high-quality and skilled innovative talents.

\subsection{Innovate the teaching concept of professional courses}

Based on the "OBE" teaching philosophy, with students as the main teachers as the auxiliary, pay attention to teaching and learning of the achievement consciousness. Correctly understand and handle the relationship between knowledge imparting, curriculum ideological and political education, innovation and entrepreneurship education and value guidance. Innovating the three-in-one education concept of "full staff, whole process and all-round", Fully explore the ideological and political moral education function of professional courses, and effectively integrate innovation and entrepreneurship education into professional course teaching. cultivate people with morality. Emphasis on teaching is more important than education

\subsection{Reconstruction of curriculum knowledge system}

Adhere to the student-oriented. Incorporating ideological and political elements into the teaching content. Break down the theoretical and practical barriers. Reconstruction of the "module + platform" professional curriculum theory course and practice course system, modular teaching of theoretical knowledge content. Grasp the industry dynamics and market demand, university-enterprise cooperation, build, optimize and improve a diversified practice teaching platform, strengthen in-class and extra-curricular curriculum experiments and practice teaching content. Make full use of information technology means to build into "strong" education professional hybrid, diversified curriculum resources, make full use of the learning and flip classroom network platform, based on competition disciplines and laboratory, college and enterprise jointly established discipline design competition for college students, the virtual simulation experiment with teaching practice, improve teachers' teaching ability, "Promote learning through competition, promote training through competition, promote innovation through competition and combine training with competition", highlighting the cultivation of students' professional ability and innovation and entrepreneurship ability. Make full use of information means to increase the construction of MOOCs and micro courses, focus on building a normal online teaching resource platform, and build online and offline mixed and diversified courses Curriculum ideological and political education, Innovation and entrepreneurship education resource supply. Explore new research ideas of "innovation" education curriculum, and give full play to the role of "innovation" education content in value guidance and innovation and entrepreneurship education infiltration. Scientific ethics, innovation and entrepreneurship education in a silent way into the process of practical teaching.

\subsection{Improving teachers' ability to teach ideological and political education, innovation and entrepreneurship in team courses}

Teachers are the main force of higher education, the theme of curriculum ideological and political education, innovation and entrepreneurship education, and the first responsible person of classroom teaching. Under the new engineering background, teachers should 
change their teaching thinking, renew their educational ideas, broaden their educational ideas, internalize lide and cultivate talents in their heart, and externalize and practice. In teaching practice, we should be good at using moral education method of ideological and political education and actively use information carrier to organically integrate knowledge imparting, innovation and entrepreneurship ability cultivation and value guidance into the whole teaching process of each course. The teacher team should continue to strengthen learning, attend lectures, actively participate in weekly teaching and research activities, discuss the specific implementation methods of "thinking and innovation education", fully explore the ideological and political elements of the curriculum, and form a teaching guide. More research on curriculum ideological and political education and innovation and entrepreneurship education related literature, publish more papers, apply for all kinds of teaching and research projects at all levels, constantly improve curriculum ideological and political education and innovation and entrepreneurship education teaching ability, improve the quality of classroom teaching. Strengthen school-enterprise cooperation, deepen the integration of industry and education, enterprise teachers follow classes, introduce enterprise culture, certification standards of mainstream enterprises and enterprise resources into teaching, keep pace with The Times, keep up with the forefront of The Times, and integrate the theoretical knowledge of "Innovation" education into work practice.

\subsection{Optimizing curriculum system assessment}

Change the assessment concept of the curriculum system, construct a three-dimensional and diversified assessment scheme, and on the basis of the original evaluation system, construct a quality-oriented curriculum ideological and political goal evaluation curriculum evaluation system, improve the teacher incentive evaluation mechanism, and students' learning effectiveness evaluation system. Make Curriculum ideological and political education, Innovation and entrepreneurship education observable, predictable and assessable. Enriching curriculum assessment indicators, integrating evaluation subjects, evaluation objects and evaluation indicators, is conducive to improving students' enthusiasm in learning and the process of students' unity and cooperation in learning. It is beneficial to stimulate students' subject consciousness. Course assessment mainly includes online assessment and offline assessment. The online assessment is combined with the Superstar learning platform, and a reasonable proportion of the score is assigned according to the completion of course resources. Offline assessment mainly includes process assessment. The assessment system will run through the course assessment in the whole process of teaching.

\section{Researching significance}

Under the new situation of engineering, vocational education in higher vocational colleges should focus on cultivating innovative talents with high quality and technical skills. Technology innovative skills talent cultivation, the first to encourage the development of students' innovative entrepreneurial spirit and innovation ability education idea, education mode, cultivate high-quality technical skilled talents in higher vocational colleges should strive to create the conditions, analysis of the new era of new entrepreneurial innovation national construction target under the engineering background of high quality innovative technical skill talented person's demand, Determine the training objectives of high-quality innovative technical skills talents and find the training strategies of high-quality innovative technical skills talents in innovative and entrepreneurial countries under the new engineering background. "The biggest achievement of vocational education during the 13th Five-Year Plan period is that it has trained a large number of technical talents to support economic and social development, and played an important role in serving national strategy, regional 
development, poverty alleviation and education equity," said Chen Ziji, director of the Vocational and Adult education department under the Ministry of Education. This also clarifies the type of talents that China needs at this stage -- those with the ability to analyze and solve problems, the spirit of innovation and entrepreneurship, and professional skills. Under the background of new engineering, the construction of professional curriculum system in higher vocational colleges is a major bottleneck that affects and restricts talent cultivation. In the field of vocational education, an important construction of China's "fourteenth Five-year Plan" is to improve the general vocational integration system, curriculum sharing, and promote the resource sharing and concept reference between vocational education and general education. We will integrate entrepreneurship and innovation education with ideological and political education, professional education, career development, practical training, internship and employment, and encourage high-quality employment through innovation and entrepreneurship. Therefore, for the current shortage of technical and applied talents in China, it is very important to efficiently integrate Curriculum ideological and political education, Innovation and entrepreneurship education into the construction of professional curriculum system under the background of new engineering, which is of great significance to higher education itself and the employment orientation of the whole society.

\subsection{Theoretical significance of research}

Reconstructing the curriculum knowledge system, paying more attention to the construction of moral integration and innovative construction of curriculum ideological and political practice. Enrich and improve the construction of application-oriented college professional course system and knowledge system, provide a new practical direction for the cultivation mode and specialty setting of disciplines, and provide ideas for the construction of traditional engineering course system. The teaching reform under the guidance of the new engineering construction returns to the education level.

\subsection{Practical significance of research}

This study further strengthens the curriculum ideological and political construction, innovation and entrepreneurship education, improves the professional talent training system, innovates the teaching content, teaching means and methods, and speeds up the training of high-quality technical and skilled innovative talents, in line with the requirements of the development of The Times, so as to cultivate high-end application-oriented talents to meet the needs of The Times. It serves the needs of national and local economic development and is conducive to accelerating the transformation of economic development mode. It is also the need of deepening the reform of higher education in Shandong Province. It has deepened the integration of industry and education and effectively carried out cooperation with employers. Course education through the way of the recessive penetration, the ideological education, innovation, entrepreneurship education into the professional course, develop its cooperative education effect, helps to promote students' moral cultivation, innovative entrepreneurial spirit and the professional spirit, promote the diversity of students' professional development, meet the demand of students' growth development and expectation, in the future jobs impregnable in the fierce competition. 


\section{Conclusion}

To explore how to efficiently integrate Curriculum ideological and political education, Innovation and entrepreneurship education into the construction of professional curriculum system under the background of new engineering, to provide reference and demonstration for talent cultivation under the background of new engineering, to other related professional training, and to the reform of other colleges and universities in China. It plays an important demonstration and radiating role in the integration of subjects in the university and the extension of influence outside the university. It steadily improves the construction and teaching quality of specialized courses in China's colleges and universities. Timely expand the depth of integration with other disciplines in the university; Continue to expand cooperation with well-known domestic enterprises, and have a positive social impact. The trained talents can directly connect with the enterprises in the industry, and the cultivation of enterprise talents also has a good effect.

Fund Items: Ji 'nan vocational education innovation development highland theoretical practice research topic "Under the new engineering background of higher vocational colleges Curriculum ideological and political education, Innovation and entrepreneurship education into the construction of professional curriculum system. Project No. ZJGD2020302".

\section{References}

1. Lu Guodong, Li Tuoyu. Research of Higher Engineering Education,2017(03):20-26.

2. Wang Yanping. Characteristics and Implementation Path of "Three-integrity Education" in Colleges and Universities [J]. Ideological and Theoretical Education,2019(09):103106.

3. Cheng Guiying. Three focal points of promoting the Teaching reform of "Curriculum thinking and politics" [J]. Discipline Construction of Marxist Theory,2018(9):67-70.

4. Zhang Yan, LI Xin, GUO Yongpan. Research on the reform of curriculum Assessment System under blended Teaching Mode [J]. Science and Education Guide,2021(07):50$51+65$.

5. Li Haiyan. Innovation and practice of curriculum assessment in applied universities from the perspective of new Business Construction: A case study of Business major in Xinhua University of Anhui. Journal of Shanxi University of Energy, 201,34(04):16-18.

6. Shandong Provincial Department of Education. Shandong Agricultural University has done a solid job in the employment and entrepreneurship of graduates[EB/OL].http://www.moe.gov.cn/jyb_xwfb/s6192/s222/moe_1747/201910/t2 0191015_403428.html.2019-10-15.

7. Department of Vocational and Adult Education, Ministry of Education. From "level" to "type" vocational education has entered a new stage of high-quality development[EB/OL].http://www.moe.gov.cn/fbh/live/2020/52735/sfcl/202012/t20201 208_503998.html,2020-12-08. 